\title{
Inventory of Vegetation and Assessment of Carbon Storage Capacity towards a Low Carbon Campus: a Case Study of Universiti Tun Husein Onn Malaysia, Johor Malaysia
}

\author{
Audu Yunusa ${ }^{1}$, Alona Linatoc ${ }^{1}$ \\ ${ }^{1}$ Universiti Tun Hussein Onn Malaysia \\ 101 Parit Raja, Batu Pahat, Johor, 86400, Malaysia
}

DOI: $10.22178 /$ pos. $41-3$

LCC Subject Category:

QK710-899

Received 21.11.2018

Accepted 25.12.2018

Published online 28.12.2018

Corresponding Author:

Audu Yunusa

abduldaudu@yahoo.co.uk

(C) 2018 The Authors. This article

is licensed under a Creative

Commons Attribution 4.0 License

(c) (1)

\begin{abstract}
Carbon dioxide, a vital greenhouse gas plays a key role in Earth's carbon cycle, a concentration above ambient temperature results in global warming. High $\mathrm{CO}_{2}$ emission in Universiti Tun Husein Onn Malaysia is due to an increase in a number of automobiles and other greenhouse gases released from building facilities and nearby industries. A study was carried out on 22 common trees planted within the campus on the estimated amount of $\mathrm{CO}_{2}$ sequestered. Estimation of carbon storage of trees was obtained through the assessments of standing biomass as well measurement of their photosynthetic capacity. Results indicated that Spathodea campanulata has the highest $\mathrm{CO}_{2}$ absorption $\left(14.40 \mu \mathrm{mol} / \mathrm{m} \mathrm{m}^{-2} / \mathrm{s}^{-1}\right)$ followed by Acacia mangium $\left(14.03 \mu \mathrm{mol} / \mathrm{m}^{-2} / \mathrm{s}^{-1}\right)$, and Cananga odorata with $\left(12.80 \mu \mathrm{mol} \mathrm{m}^{-2} \mathrm{~s}^{-1}\right)$. Alstonia scholaris has the highest aboveground standing biomass accumulation of $106.94 \mathrm{~kg}$, followed by Samanea saman $(20.83 \mathrm{~kg})$, and Acacia mangium $(19.43 \mathrm{~kg})$. The total biomass accumulated of all the tree species is $200.03 \mathrm{~kg}$. Therefore, species of trees in Universiti Tun Husein Onn Malaysia main campus have the potential to absorb a significant amount of $\mathrm{CO}_{2}$ from the atmosphere thereby contributing to mitigating-the localized effects of global warming.
\end{abstract}

Keywords: Carbon dioxide sequestration; tropical vegetation; global warming; climate change; biomass.

\section{INTRODUCTION}

The continuous increase of carbon dioxide $\left(\mathrm{CO}_{2}\right)$ emission in the University environment is a result of the increase in the consumption of energy use from fossils fuel to power automobiles as well as to run the facilities for the effective teaching, learning, residence and administrative use within the campus. The discharge of gases from the neighbouring industry and from passing vehicles on the roadsides indicates serious implication on the quality of air in the Universiti Tun Hussein Onn Malaysia environment.

Environmentalists consider carbon dioxide $\left(\mathrm{CO}_{2}\right)$ to be the most important anthropogenic greenhouse gas [1]. However, since the beginning of the industrial revolution, the percentage increased by $39 \%$ (from $280 \mathrm{ppm}$ to $388 \mathrm{ppm}$ ) [2]. As the trend continued, $\mathrm{CO}_{2}$ increased from 280 parts per million ( $\mathrm{ppm}$ ) in
1850 to 394 ppm by 2012 [1, 3]. Presently, the concentration of $\mathrm{CO}_{2}(400 \mathrm{ppm})$ is double as large as it was witnessed in eighteen thousand years that passed [4]. To minimise the increase of $\mathrm{CO}_{2}$ concentration in the university campus and to derive benefit from trees, the situation necessitates the validation of the potential and capability of storage of carbon by the trees of Universiti Tun Hussein Onn Malaysia campus, and to find out which tree is suitable for the maximum absorption and sequestration of $\mathrm{CO}_{2}$ to reduce the concentration to a minimal level.

Carbon dioxide sequestration takes into account both natural through biological, chemical, and physical processes of removing excess carbon from the environment. Naturally, trees act as a sink for carbon dioxide $\left(\mathrm{CO}_{2}\right)$ by fixing carbon during photosynthesis and storing carbon as biomass. Trees in urban areas (i.e. urban forests) sequester and store carbon as they grow, thereby affect local climate, carbon cy- 
cles, climate change, air temperature and building energy use, and thus alter carbon emissions from many urban sources e.g., power plants [5]. Artificially it involves the elimination, capture, and sequestration of industrially produced $\mathrm{CO}_{2}$ using subsurface saline aquifers, reservoirs, ocean water, aging oil fields, or other carbon sinks [6]. Oceans perform the function of the sinking of $\mathrm{CO}_{2}$ emissions of about 2 gigatons of carbon per year $[7,8]$.

Higher $\mathrm{CO}_{2}$ in the atmosphere can increase the greenhouse consequence and excessively heat in the earth's surface, but as trees grow they absorb and store carbon in them. In the presence of increased greenhouse gases in the atmosphere, forests become even more vital for removing $\mathrm{CO}_{2}$ from the atmosphere to reduce its effects [9].

According to [10], as trees grow they absorb several tons of $\mathrm{CO}_{2}$ out off thereby decreasing summertime air temperatures from evapotranspiration and straight shading [11]. California Climate Action Team report (2006), recommended planting 5 million trees in cities to reduce 3.5 million metric tons of $\mathrm{CO}_{2}$. In their study, they discovered that by planting 1 million trees, the Million Trees LA program will decrease atmospheric $\mathrm{CO} 2$ by about 1 million tons over the next 35 years, which is like taking 7,000 cars off the road each year [12].

Authors [2] reported the ability of Peltophorum pterocarpum and Samanea saman among other trees to reach their maximum $\mathrm{CO}_{2}$ uptake rates of 24.5 and $20.9 \mathrm{CO}_{2} \mu \mathrm{mol} / \mathrm{m}^{-2} / \mathrm{s}^{-1}$, when photosynthetically active radiation is 1100 and $1500 \mu \mathrm{mol} / \mathrm{m}^{2} / \mathrm{s}^{-1}$ respectively. They suggested the species as good carbon sinks and they should be planted more in the city for optimal $\mathrm{CO}_{2}$ absorption. Authors [13] reported that total carbon storage and sequestration within cities increases with increase in urban trees cover and this is well pronounced with the increase in the proportion of large healthy trees with greater than $77 \mathrm{~cm}$ in diameter that can sequester approximately 90 times more carbon than small trees of less than $8 \mathrm{~cm}$ in diameter. In the study carried out by [14], indicate that A. saman had more biomass $(75707.31 \mathrm{~kg})$ followed by Azadirachta. indica (50203.26 kg) and $P$ pterocarpum (29476.07 kg) among other plants study in estimating urban tree biomass.

Authors [15] observe that Macaranga giggantea with large Diameter at Breast Height stored more carbon (2560 kg C) when compared to Adinandra dumosa with (391 kg C), with small Diameter at Breast Height.

Authors [16] revealed the capability of Delonix regia to have the maximum carbon accumulation of (4028.97) tons $h a^{-1}$, among other trees studied in Bhubaneswar City of Odisha, India. In another study, $\mathrm{CO}_{2}$ assimilation rate was observed to be as high as $16.61 \mu \mathrm{mol} / \mathrm{m}^{-2} / \mathrm{s}^{-1}$ in case of Polyalthia longifolia and lowest of 9.39 $\mu \mathrm{mol} / \mathrm{m}^{-2} / \mathrm{s}^{-1}$ in Bauhinia perpuria. Therefore it was suggested that species could be planted for better carbon assimilation in the University.

In the study conducted by $[17,18]$, the total carbon stock inclusive of both aboveground and belowground of all adult trees in the University campus was $2590.48 \mathrm{Mg}(8.7 \mathrm{Mg} \mathrm{C} / \mathrm{ha}$ ) and the highest carbon stock value was observed in Acacia auriculiformis. They concluded that the university campus is rich in tree species' diversity with a great carbon stocking potential similar to those of natural tropical dry forests [19], found out that Swietenia mahogany successively followed by Albezia saman, Polyalthia longifolia, Drypetes roxburghii, Mangifera indica, Saraca asoca, Dolichandrone stipulate and Lagestroemia speciosa are with high efficiency to sequester atmospheric $\mathrm{CO}_{2}$ and the present author registers Ficus benghalensis as the best in this regard. Thus, the aim of this study was to determine the inventory of plants, capacity and their importance in carbon storage in Universiti Tun Hussein Onn Malaysia campus.

\section{METHODOLOGY}

The study was carried out at Universiti Tun Husein Onn Malaysia main campus with coordinate $1.8531^{\circ} \mathrm{N}, 103.0864^{\circ}$. There are 11,403 registered cars as of 21st February 2018. The overall area cover of the campus is 238.896 hectares. Out of this figure, 152.667 hectares are developed, while the remaining area stands as undeveloped / reserved. The trees within the Universiti Tun Husein Onn Malaysia main campus were surveyed and identified according to [20].

A significant statistics on the tree varieties and well-preserved samples of trees collected were deposited at Universiti Tun Husein Onn Malaysia botany repository for future research references. The study was conducted for quantifica- 
tion of $\mathrm{CO}_{2}$ intake by the trees through the measurement of $\mathrm{CO}_{2}$ absorption capacity of the trees. The instrument Li-6400 Portable Photosynthesis System was used to measure the $\mathrm{CO}_{2}$ photosynthetic assimilation rate. For a good estimation of $\mathrm{CO}_{2}$ and to avoid fluctuation during measurement the air flow was set to 500 $\mu \mathrm{mol}, \mathrm{CO}_{2}$ at $360 \mu \mathrm{mol}$, block temperature $30{ }^{\circ} \mathrm{C}$ and photosynthetic active radiation light at $1000 \mu \mathrm{mol} / \mathrm{m}^{-2} / \mathrm{s}^{-1}$. However, the biomass accumulation of carbon by the trees was estimated through the procedure below.

A non-destructive method was used to estimate the biomass of different trees based on the Diameter at Breast Height and tree height. The Diameter at Breast Height was calculated by measuring tree diameter at breast height, approximately 1.3 meters above the ground. The diameters of trees were measured directly by the measuring tape (D-tape). The tree height was measured by the use of Theodolite instrument.

The general multi-species biomass equation $Y=\exp \left\{3.2249+0.9885 \operatorname{In}\left(d^{2} h\right)\right\}$ develops by [21] for estimating the total aboveground standing biomass of trees was used.
The below ground biomass was calculated by multiplying AGB (Kg/tree) or (ton/tree) $\times$ BGB $\mathrm{Kg} /$ tree (0.26) [22].

The Leaves Carbon Content was obtained by the leaf ash method by [23], and the resulting ash content was used to determine the leave carbon content of the study plants.

\section{RESULTS AND DISCUSSION}

The species of trees in Universiti Tun Husein Onn Malaysia studied in their capacity had the potential to absorb and store $\mathrm{CO}_{2}$ (biomass accumulation) through the process of photosynthesis. Trees play important role in carbon storage to reduce the emission of $\mathrm{CO}_{2}$ in the atmosphere. The knowledge of numbers of trees and their potentials in the absorption and storage of $\mathrm{CO}_{2}$ will give an insight on how to increase the numbers of trees by allocating space for planting more trees that can function in reducing of environmental pollution and $\mathrm{CO}_{2}$ emission in the environment [24].

The result of the study is shown in (Table 1 , Figures 1-2), total standing biomass and $\mathrm{CO}_{2}$ absorption capacity rate is estimated.

Table 1 - Showing quantifies of biomass accumulation of common species of trees and $\mathrm{CO}_{2}$ absorption capacity.

\begin{tabular}{|l|l|c|r|r|r|r|r|r|}
\hline No & Species Scientific Name & $\begin{array}{c}\text { No of } \\
\text { individuals }\end{array}$ & $\begin{array}{r}\text { CO2 Assimilation } \\
\left(\mu \mathrm{mol} / \mathrm{m}^{-2} / \mathrm{sec}^{-1}\right)\end{array}$ & LAI $\left(\mathrm{cm}^{2}\right)$ & STC & S/F & LCC $(\mathrm{kg})$ & TSB $(\mathrm{kg})$ \\
\hline 1 & T. rosea & 1505 & $4.97 \pm 1.62$ & $1.04 \pm 0.02$ & $6.00 \pm 2.52$ & 0.26 & 0.02 & $2.3 \pm 0.01$ \\
\hline 2 & L. speciosa & 1007 & $4.96 \pm 3.84$ & $1.20 \pm 0.09$ & $3.00 \pm 0.58$ & 0.04 & 0.02 & $0.15 \pm 0.03$ \\
\hline 3 & F. benjamina & 677 & $9.42 \pm 2.15$ & $0.21 \pm 0.02$ & $14.00 \pm 1.73$ & 0.06 & 0.01 & $0.2 \pm 0.03$ \\
\hline 4 & S. saman & 486 & $7.68 \pm 3.20$ & $0.50 \pm 0.00$ & $14.00 \pm 2.65$ & 1.13 & 0.03 & $20.83 \pm 0.02$ \\
\hline 5 & C. verum & 373 & $9.12 \pm 1.11$ & $0.43 \pm 0.15$ & $7.00 \pm 0.58$ & 0.07 & 0.02 & $0.31 \pm 0.04$ \\
\hline 6 & P. pterocarpum & 276 & $9.79 \pm 0.83$ & $0.08 \pm 0.00$ & $19.00 \pm 7.02$ & 0.41 & 0.01 & $4.26 \pm 0.02$ \\
\hline 7 & E. fusca & 179 & $12.03 \pm 2.36$ & $0.21 \pm 0.12$ & $8.00 \pm 2.89$ & 0.06 & 0.01 & $0.2 \pm 0.001$ \\
\hline 8 & M. elengi & 171 & $5.98 \pm 0.58$ & $0.47 \pm 0.03$ & $8.00 \pm 2.00$ & 0.13 & 0.01 & $0.65 \pm 0.03$ \\
\hline 9 & C. junghuhniana & 165 & $4.41 \pm 0.06$ & $0.10 \pm 0.00$ & $5.00 \pm 1.00$ & 0.1 & 0.02 & $1.54 \pm 0.01$ \\
\hline 10 & C. odorata & 143 & $12.80 \pm 1.77$ & $1.11 \pm 0.04$ & $24.00 \pm 2.31$ & 0.05 & 0.02 & $0.1 \pm 0.01$ \\
\hline 11 & S. campanulata & 132 & $14.40 \pm 4.06$ & $0.56 \pm 0.06$ & $45.00 \pm 16.46$ & 0.27 & 0.01 & $2.28 \pm 0.05$ \\
\hline 12 & M. indica & 111 & $6.63 \pm 3.87$ & $0.82 \pm 0.14$ & $14.00 \pm 2.64$ & 0.81 & 0.02 & $10.7 \pm 0.08$ \\
\hline 13 & X. chrysanthus & 87 & $9.54 \pm 0.40$ & $0.42 \pm 0.08$ & $21.00 \pm 1.73$ & 0.16 & 0.01 & $1.05 \pm 0.06$ \\
\hline 14 & P. longifolia & 67 & $5.2 \pm 0.21$ & $0.69 \pm 0.13$ & $12.00 \pm 1.53$ & 0.23 & 0.02 & $1.8 \pm 0.08$ \\
\hline 15 & K. senegalensis & 65 & $5.29 \pm 0.12$ & $0.46 \pm 0.04$ & $41.00 \pm 13.50$ & 0.51 & 0.03 & $6.99 \pm 0.04$ \\
\hline 16 & A. scholaris & 53 & $8.5 \pm 1.19$ & $0.58 \pm 0.7$ & $41.00 \pm 9.50$ & 3.04 & 0.01 & $106.94 \pm 0.01$ \\
\hline 17 & C. equisetifolia & 52 & $1.91 \pm 0.15$ & $0.39 \pm 0.45$ & $33.00 \pm 7.02$ & 0.05 & 0.02 & $1.04 \pm 0.001$ \\
\hline 18 & F. frangrans & 48 & $9.71 \pm 4.48$ & $0.26 \pm 0.03$ & $8.00 \pm 2.00$ & 0.98 & 0.03 & $17.28 \pm 0.03$ \\
\hline 19 & S. polyanthum & 47 & $9.16 \pm 0.11$ & $0.54 \pm 0.12$ & $46.00 \pm 917$ & 0.08 & 0.02 & $0.32 \pm 0.01$ \\
\hline 20 & S. grande & 45 & $4.54 \pm 1.42$ & $1.58 \pm 0.13$ & $41.00 \pm 3.79$ & 0.2 & 0.02 & $1.63 \pm 0.02$ \\
\hline
\end{tabular}




\begin{tabular}{|c|l|c|c|c|r|r|r|r|}
\hline No & Species Scientific Name & $\begin{array}{c}\text { No of } \\
\text { individuals }\end{array}$ & $\begin{array}{c}\text { CO2 Assimilation } \\
\left(\mu \mathrm{mol} / \mathrm{m}^{-2} / \mathrm{sec}^{-1}\right)\end{array}$ & LAI $\left(\mathrm{cm}^{2}\right)$ & STC & S/F & LCC $(\mathrm{kg})$ & TSB $(\mathrm{kg})$ \\
\hline 21 & P pinnata & 43 & $8.56 \pm 0.75$ & $1.05 \pm 0.10$ & $45.00 \pm 10.54$ & 0.07 & 0.01 & $0.05 \pm 0.01$ \\
\hline 22 & A. mangium & 42 & $14.03 \pm 0.55$ & $0.93 \pm 0.07$ & $31.00 \pm 8.54$ & 1.05 & 0.02 & $19.43 \pm 0.04$ \\
\hline \multicolumn{2}{|c|}{ Total number } & 5716 & 181.45 & & & & & 200.03 \\
\hline
\end{tabular}

Notes: S/F - Species Factor, TSB - Total Standing Biomass, LCC - Leaf Carbon Content, LAI - Leaf Area Index, STC - Stomatal Count.

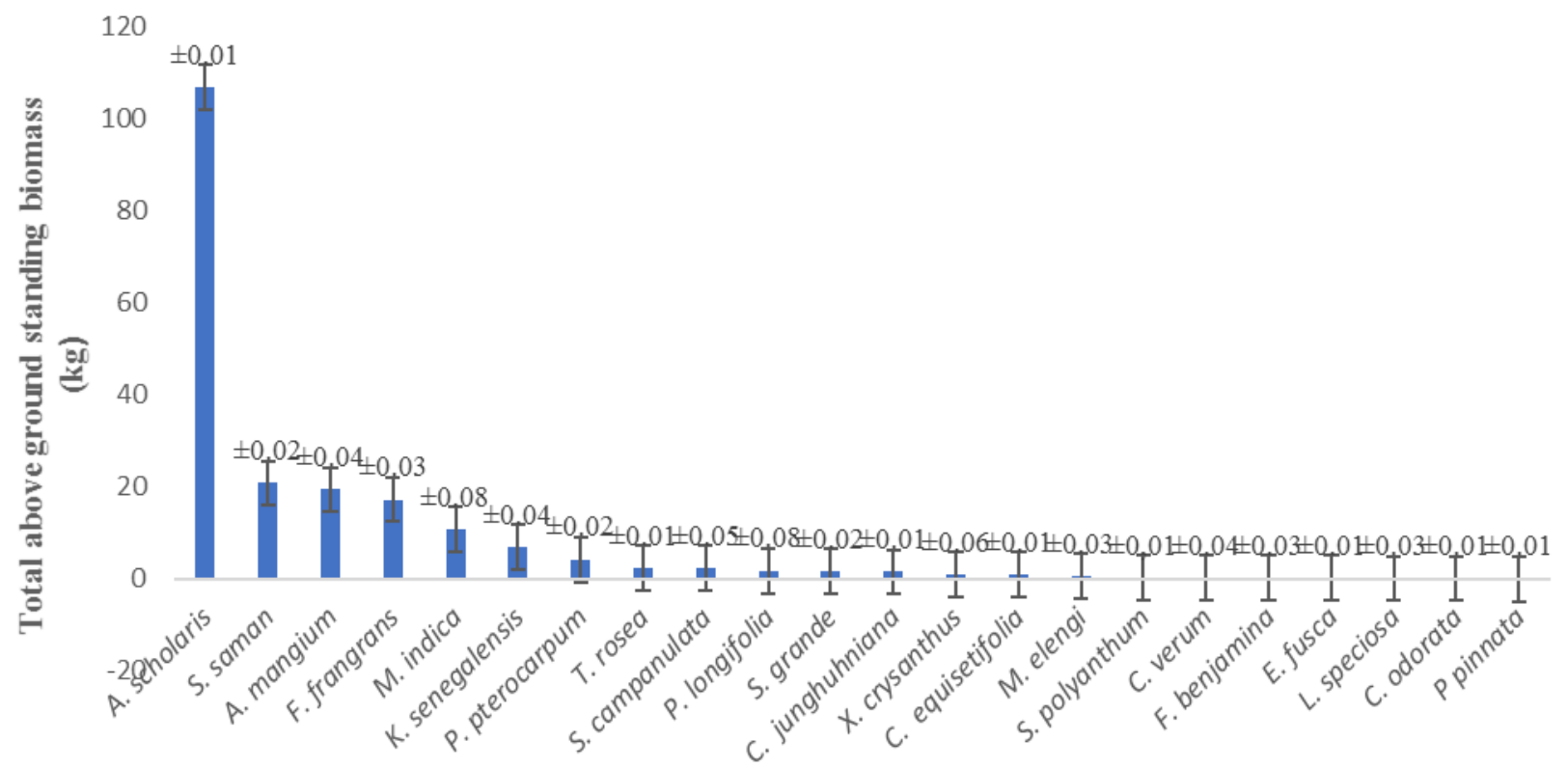

Figure 1 - Graph showing total above ground standing biomass

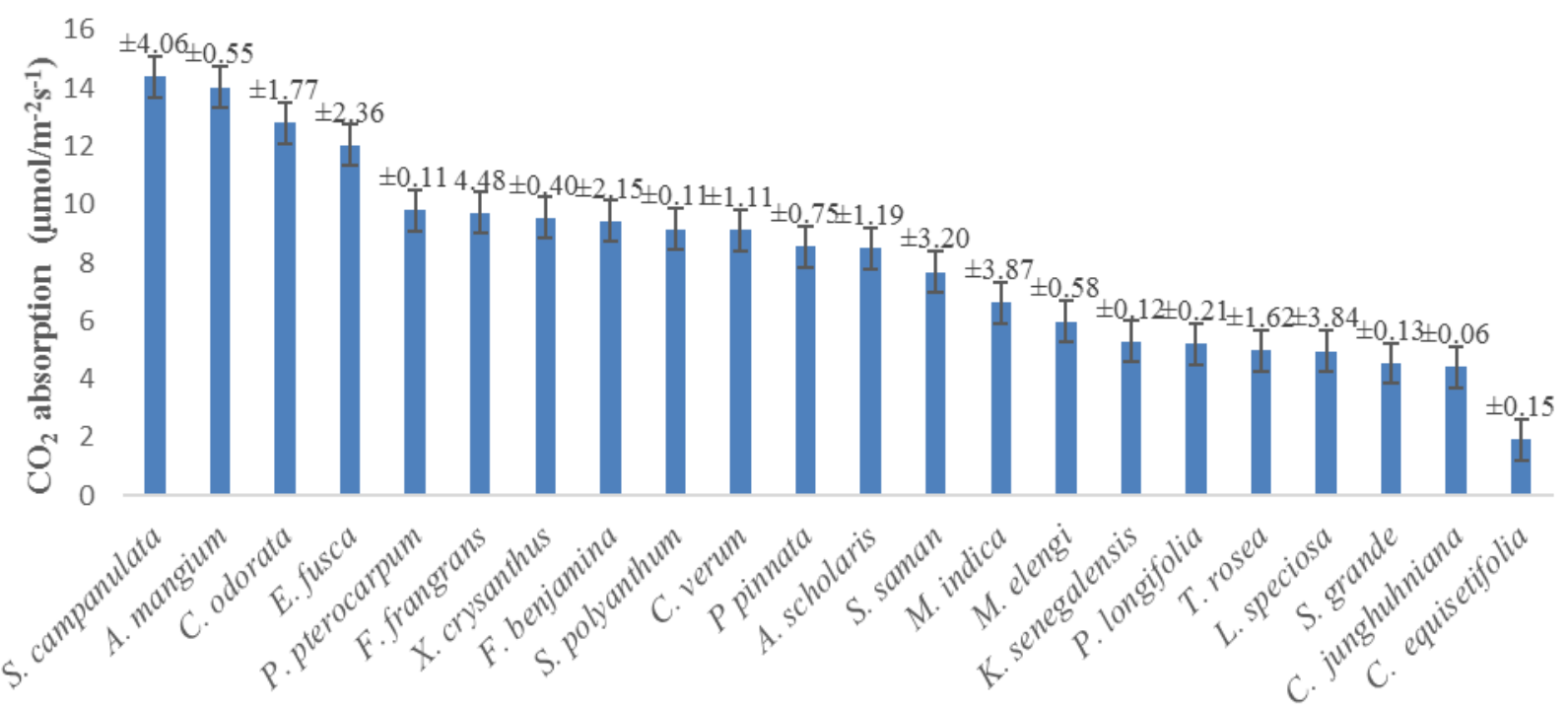

Figure 2 - Graph Showing C02 Absorption

It was observed that A.scholaris sequestered $106.94 \mathrm{~kg} /$ tree, which is the highest compared to other tree species from the study area. This could be due to higher Diameter at Breast Height and height of the trees (15.40 heights, 2.28 Diameter at Breast Height), with a total number of 53 species [20, 21]. This is followed by $S$. saman with $20.83 \mathrm{~kg}$ with a total number of 486 species and A.mangium with $19.44 \mathrm{~kg}$. $P$. pinnata sequestered the lowest $\mathrm{CO}_{2}$ of $0.05 \mathrm{~kg}$ with 43 species which probably might be due to lower Diameter at Breast Height of 
$0.17 \mathrm{~m}$ [20], reported that large trees store nearly 90 times more carbon than smaller trees. However, from the findings, $S$. campanulata was found to have the highest $\mathrm{CO}_{2}$ absorption $\left(14.40 \mu \mathrm{mol} / \mathrm{m}^{-2} / \mathrm{s}^{-1}\right)$. While $C$. equisetifolia $\left(1.91 \mu \mathrm{mol} / \mathrm{m}^{-2} / \mathrm{s}^{-1}\right)$ has the lowest $\mathrm{CO}_{2}$ absorption.

\section{CONCLUSION}

Trees in urban setting play a significant role in the reduction of atmospheric carbon dioxide level. From the result obtained, $A$. scholaris has a higher and better $\mathrm{CO}_{2}$ accumulation rate, whereas, $P$. pinnata sequestered the lowest. $S$. campanulata was found to have the highest $\mathrm{CO}_{2}$ absorption. Therefore, the above species could be recommended for planting in the university campus for better sequestration and assimilation of carbon from the atmosphere and to enrich the quality of air in campus and the nearby community.

\section{REFERENCES}

1. Stangeland, A. (2007). A model for the CO2 capture potential. International Journal of Greenhouse Gas Control, 1(4), 418-429. doi: 10.1016/s1750-5836(07)00087-4

2. Suwanmontri, C., Kositanont, C., \& Panich, N. (2013). Carbon Dioxide Absorption of Common Trees in Chulalongkorn University. Modern Applied Science, 7(3). doi: 10.5539/mas.v7n3p1

3. Ahmedin, A. M., Bam, S., Siraj, K. T., \& Raju, A. S. (2013). Assessment of biomass and carbon sequestration potentials of standing Pongamia pinnata in Andhra University, Visakhapatnam, India. Bioscience Discovery, 4(2), 143-148.

4. Gore, A. (2014, June 18). The Turning Point: New Hope for the Climate. Rolling Stone, 18. Retrieved from https://www.rollingstone.com/politics/politics-news/the-turning-point-new-hope-forthe-climate-81524

5. Alamgir, M., \& Al-Amin, M. (2007). Organic carbon storage in trees within different Geopositions of Chittagong (South) Forest Division, Bangladesh. Journal of Forestry Research, 18(3), 174-180. doi: 10.1007/s11676-007-0036-6

6. Sundquist, E. T., Burruss, R. C., Faulkner, S. P., Gleason, R. A., Harden, J. W., Kharaka, Y. K., ... \& Waldrop, M. P. (2008). Carbon sequestration to mitigate climate change. Retrieved from https://pubs.usgs.gov/fs/2008/3097/pdf/CarbonFS.pdf

7. Nanda, S., Reddy, S. N., Mitra, S. K., \& Kozinski, J. A. (2016). The progressive routes for carbon capture and sequestration. Energy Science \& Engineering, 4(2), 99-122. doi: 10.1002/ese3.117

8. Cheah, W. Y., Ling, T. C., Juan, J. C., Lee, D.-J., Chang, J.-S., \& Show, P. L. (2016). Biorefineries of carbon dioxide: From carbon capture and storage (CCS) to bioenergies production. Bioresource Technology, 215, 346-356. doi: 10.1016/j.biortech.2016.04.019

9. Goodale, C. L., Apps, M. J., Birdsey, R. A., Field, C. B., Heath, L. S., Houghton, R. A., ... \& Shvidenko, A. (2002). Forest carbon sinks in the Northern Hemisphere. Ecological applications, 12(3), 891-899.

10. McPherson, E. G., \& Simpson, J. R. (1999). Carbon dioxide reduction through urban forestry: guidelines for professional and volunteer tree planters. doi: 10.2737/psw-gtr-171

11. McPherson, E. G., \& Simpson, J. R. (2003). Potential energy savings in buildings by an urban tree planting programme in California. Urban Forestry \& Urban Greening, 2(2), 73-86. doi: 10.1078/1618-8667-00025

12. McPherson, G., Simpson, J., Xiao, Q., \& Wu, C. (2007, March 31). Los Angeles One Million Tree Canopy Cover Assessment Final Report. Retrieved from https://www.sactree.com/assets/files/greenprint/UrbanForestforCleanAir/psw_cufr689a_Milli onTreesLA_final_web.pdf 
13. Nowak, D. J., \& Crane, D. E. (2002). Carbon storage and sequestration by urban trees in the USA. Environmental pollution, 116(3), 381-389.

14. Udayakumar, S., M. and Sekar, T. (2015). Estimation of urban tree biomass in Pachaiyappa's College, Chennai, India. Scholars Academic Journal of Biosciences, 3(4), 338-347.

15. Isa, N., Ismail, S., \& Reba, M. (2014). Carbon stock of Macaranga gigentia and Adinandra dumosa. International Alliance for Sustainable Urbanization and Regeneration, 69-76. Retrieved from http://builtsurvey.utm.my/ismail/files/2015/01/1-2.pdf

16. Mitra, A., Bagchi, J., Parkhi, S. T. U., Debnath, S., Pramanick, P., \& Zaman, S. (2015). Carbon sequestration in Bhubaneswar City of Odisha, India. International Journal of Innovative Research in Science, Engineering and Technology, 4(8), 6942-6947.

17. Sundarapandian, S. M., Amritha, S., Gowsalya, L., Kayathri, P., Thamizharasi, M., Dar, J. A., ... \& Gandhi, D. S. (2014). Biomass and carbon stock assessments of woody vegetation in Pondicherry University campus, Puducherry. International Journal of Environmental Biology, 4(2), 87-99.

18. Ganguly, S., \& Mukherjee, A. (2016). A census of the tree species in the golapbag campus of burdwan university, West Bengal (India) with their iucn red list status and carbon sequestration potential of some selected species. Indian Journal of Scientific Research, 7(1), 67.

19. Eneji, I. S., Obinna, O., \& Azua, E. T. (2014). Sequestration and Carbon Storage Potential of Tropical Forest Reserve and Tree Species Located within Benue State of Nigeria. Journal of Geoscience and Environment Protection, 02(02), 157-166. doi: 10.4236/gep.2014.22022

20. Djomo, A. N., Ibrahima, A., Saborowski, J., \& Gravenhorst, G. (2010). Allometric equations for biomass estimations in Cameroon and pan moist tropical equations including biomass data from Africa. Forest Ecology and Management, 260(10), 1873-1885. doi: 10.1016/j.foreco.2010.08.034

21. Gedefaw, M., Soromessa, T., \& Belliethathan, S. (2014). Forest Carbon Stocks in Woody Plants of Tara Gedam Forest: Implication for Climate Change Mitigation. Science, Technology and Arts Research Journal, 3(1), 101. doi: 10.4314/star.v3i1.16

22. Peacock, T. R. (1992). The preparation of plant material and determination of weight percent ash. Retrieved from https://pubs.usgs.gov/of/1992/0345/report.pdf

23. Zhao, M., Escobedo, F. J., \& Staudhammer, C. (2010). Spatial patterns of a subtropical, coastal urban forest: Implications for land tenure, hurricanes, and invasives. Urban Forestry \& Urban Greening, 9(3), 205-214. doi: 10.1016/j.ufug.2010.01.008

24. MacDicken, K. G. (1997). A guide to monitoring carbon storage in forestry and agroforestry projects. Arlington: Winrock International Institute for Agricultural Development. 